\title{
Applicability of Hajnal line: impact of culture on country performance in current era
}

\author{
Lucia Kohnová ${ }^{\text {[0000-0003-4787-3901] }}$ and Ján Papula ${ }^{20000-0002-5761-9213] ~}$ \\ ${ }^{1}$ Faculty of management, Comenius University, Bratislava, Slovakia \\ ${ }^{2}$ Faculty of management, Comenius University, Bratislava, Slovakia \\ lucia.kohnova@fm.uniba.sk, jan.papula@fm.uniba.sk
}

\begin{abstract}
The influence of culture on the behavior of organizations is already unquestionable today. However, researchers are still trying to identify the relationships between culture and business behavior, as well as to differentiate countries based on cultural specificities. Many of the models and theories used are constantly criticized, especially in terms of methodological as well as lack of data or the unsustainability of the model in terms of time. In our research, unlike other research in the field of culture, we follow on Hajal's model, a line that culturally divides Europe into two parts. Hajnal line is based on data from the pre-industrial era, while in our research we are based on data for 2017. In the research, we tested 31 European countries, using secondary data of the European innovation index, human development (HDI) and GDP per capita. Using cluster analysis and correlation analysis, we have come to conclusions that highlight the importance of examining the Hajnal line today and highlight the similarities that manifest themselves not only from an anthropological point of view but also from a corporate point of view.
\end{abstract}

Keywords: culture, business performance, Hajnal line.

\section{$1 \quad$ Introduction}

The way and intensity of how the culture influences behavior of companies has been an important topic in scientific debates. Culture could be defined in many ways, while it is based values, mind-set, beliefs, morals, habits etc.. Following Hofstede, „culture is the collective programming of the mind that distinguishes the members of one group or category of people from others" (Hofstede, 1980). The national culture and it strength has proven to have an effect on neural pathways and thus can effect individual day-today work, information or data interpretation even the way one draws conclusions (Zaltman, 2003, Livermore, 2011, Senge, 2006). People's values evolve and are influenced by various factors, such as religion, education, legal systems, family values or the political system (Brooks, 2003). Many authors have researched culture and are looking for suitable parameters or dimensions based on which cultures can be distinguished or classified. Parson and Shills (1951) named five types of patterns in behavior, each of which was a decision in a pair such as universalism vs. particularism or self-orientation vs. collectivity orientation. For example, Hall (1976) divided cultures based on the way 
people prefer to communicate (implicit / explicit information). Since culture can be examined from the point of view of individuals, organizations or nations, it was appropriate to identify what can be considered a national culture. Inkles and Levinson (1969) talk about the nation character, ie the most common personality type in the nation. Bartles (1967) also, as one of the forerunners of modern theories, identified key areas on the basis of which national cultures can be distinguished: "Law; Respect for individuality, Nature of Power and Authority; Rights of Property; Concept of Deity; Relation of Individual to State; National Identity and Loyalty; Values, Customs and Mores". The best-known author in the field of national culture is Hofstede, who builds on previous theories and first identified 4 areas, dimensions (Power Distance; Individualism / Collectivism; Uncertainty Avoidance; Masculinity / Feminity) (Hostede, 1980) with his extensive research. Later, fifth dimension was added to the previous four - "Confucian dynamism", later simply referred to as short-term and long term orientation (Hostede, Bond 1988). In view of this, Hofstede is an important cited author, however has many critics of his theory.

Another view of the division of cultures, specifically in Europe, is the Hajnal line, where the key parameters were the different levels of nuptiality. Unlike to previously mentioned authors, Hajnal made his assumptions based on data from pre-industrial era - much older data compared to "modern" authors. However, in each of the views of individual authors we can find similar features as described by Brooks (2003) that shape culture and where we can find significant differences that can affect the behavior of people and organizations.

Many authors have concluded that national culture influences the organizational culture of companies (Nazariana et al. 2017, Nelson, Gopalan 2003), according to LópezDuarten et al. (2016) also has a significant influence on the strategic decisions of companies. Meehan et. Al. (2008) take this theory even "higher", arguing that culture is the main distinguisher between high-performing countries and those lagging behind or ordinary nations.

Several authors point to the need for research conducted in non-Western countries, given that much research is "highlighting" western nations and is based on larger and more comprehensive data from Western countries (Smith 2010, Murphy, Li 2012).

\section{$2 \quad$ Literature review}

In 1965, John Hajnal described a line that runs across Europe from Saint-Petersburg to Trieste. According to Hajnal, this line separates territories, ie countries that were more typical of later marriages and those where children tended to leave the original household and start a new one (Hajnal, 1965). Following Hajnal, Reher (1998) describes northern and western European countries as those where family ties are weaker, while southern and eastern countries as those where family ties are stronger, and these differences have existed in society for many centuries. Hajnal's study became highly cited, followed by many other studies. Given that Hajnal's theory of the division of Europe is undoubtedly related to cultural issues, many authors have tested the effects of policies on marital patterns or fertility choices (Kohler et al. 2002, Gauthier, 2004). 
Gauthier (2004) states in his findings that some, but not all, of policies can affect individuals' decisions. Policies can affect the timing of parenthood, but not, for example, the number of children planned, or the decision to have children in general.

If we do not look at the detailed parameters of research in the theory of the Hajnal line, we can say that there are different household arrangements on both sides of the line. These settings on the western part of the Hajnal line were rather individualistic (Laslett, 1988), so the habit was to become independent from the family and family nest and create one's own. On the other hand, southern and eastern Europe is characterized by a more collectivist approach - common household, closeness to family, community (Verdon, 1998). In both cases, however, individual cases and groups were not taken into account, which may differ from the overall sample. Using the example of Polish households, Szołtysek and Rzemieniecki (2005) found that many young adults wanted to be independent from their families, while their decisions could also be influenced by socio-economic circumstances. In this case however, the countries that lay on the Hajnal line can in fact have more similarities with both sides, while they are closer to the western regions and thus could be historically effected more significantly that those that lay further from the line.

In the academic literature in the field of cultural research authors call for new, more precise and generalizable dimensions. Namely in the context of national culture and its impact on different behaviors of businesses. Although Hajnal line divides countries into two units, some authors also question such a generalization (Sklar, 1974), as they identified elements and features of Western behavior within family patterns also in Eastern European countries. Szołtysek (2012), based on research as well as criticism of Hajnal's line, directs research to "transitional lines" rather than strict or unchanging. Following Dingsdale (1999), "since 1989, east-central Europeas witnessed a series of transformations which have resulted in the region's geopolitical and geoeconomic repositioning within Europe, facilitating a creation of a new hierarchy of places within an" old "geographical space" . Thus many authors argue that the old Hajnal line will not be suffiecent for today, and it can be expected that even if research does not point to other forms of these lines, they are likely to move east (Szołtysek, 2012). Kasearu \& Kutsar, (2011), however, pointed to the fact that the cultural aspects of individual countries are different and thus their response to "westernization" may be different, Szołtysek's claiming it is too general and unsubstantiated. A country that has undergone significant changes since 1990 is, for example, Estonia, where after gaining independence from the Soviet Union, the number of marriages decreased rapidly by 2010 , and childbirth earlier than marriage (Kutsar et al. 2012). Kutsar et al. specified changes in the Estonian families, while in recent years the individualism of young people and the will to become independent from the family have gained on strength. Even with respect to different political regimes and division of power during the $20^{\text {th }}$ century, the current characteristics of Estonia described by Kutsar et al. seem to be perfectly in line with Hajnal's line, that was created based on much older data, characteristics of culture in pre-industrial era.

In the current literature many authors make research on culture, drawing from most recent "updates" of popular cultural theories such Hofstede's culture dimensions. However current research lacks the research perspective of durability of cultural specifics 
such as drawing from Hajnal's research, and testing the theory with current data. Following Kirkman et al. (2006), country and culture should not be studied separately, nor should be culture made equal to country, they should be studied as two variables.

\section{$3 \quad$ Materials and methods}

The aim of this article is to test the applicability of Hajnal's culture theory on current country performance in selected European countries. Countries in Europe were selected by the availability of data, while we drove data from three datasets. We used European innovation index, HDI (Human development index) and GDP per capita.

European Innovation Scoreboard work with calculated index based on several indicators divided into four areas: framework conditions, investments, innovation activities and impacts. Within the area of framework conditions, innovation index counts with education, however looks only at indicators as new doctorate graduates, population aged 25-34 with tertiary education and lifelong learning. Education as a whole system is not a part of innovation index, however it is a part of Human development index.

Human development index (HDI) measures dimensions of human development with indicators such: life expectancy, expected years of schooling, mean years of schooling, or standard of living (measured by GNI). To complete these indexes, we have chosen to include GDP per capita in our model. GDP as the economic outcome was tested with different weights in the model, first GDP per capita in 1000000 , second GDP per capita in 100000 .

The dataset consisted of 31 European countries, while the latest data available for all countries and indexes were from 2017. For data analysis we used cluster analysis to calculate k-Means. To identify the relations among tested indexes we have used Pearson's correlation.

\section{$4 \quad$ Results}

First, we looked at the data from our model. To control for the development of the index among countries, we have compared index from 1990 (Figure 1. red label) with the mean value between years 2000-2017 (using years 2000, 2010, 2012, 2014, 2015, 2016 and 2017). For some countries where HDI was measured, the data for 1990 were not available. Countries ranked in Figure 1 show countries starting with highest mean value of HDI index, where top 3 countries in the ranking were Norway, Switzerland and Germany. The standard deviation has proven, that among countries we cannot observe any significant deviations in the tested period of time. 


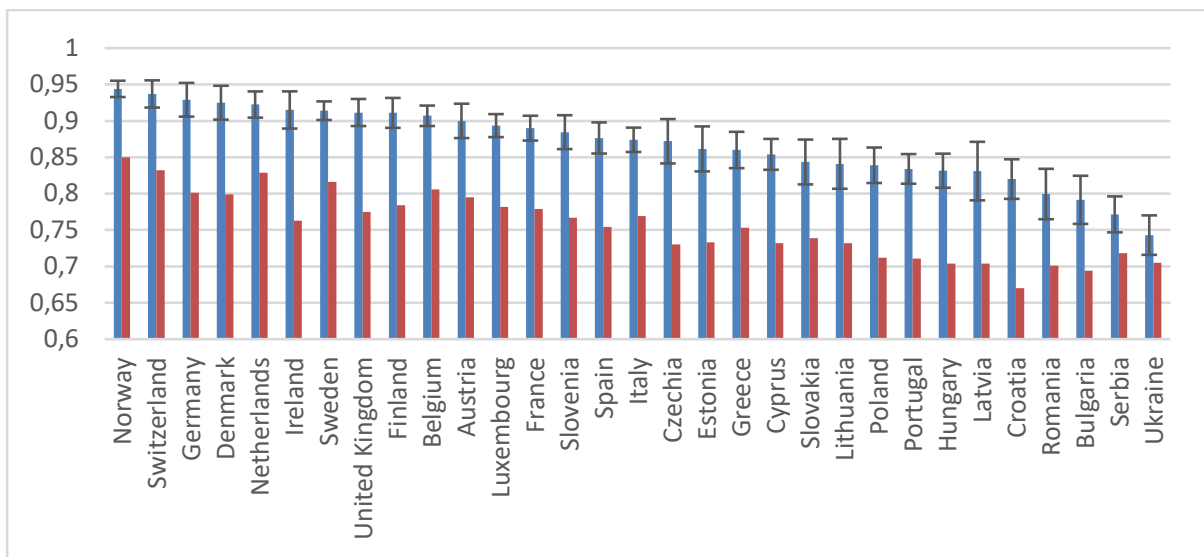

Figure 1: Mean value distribution and standard deviation for HDI index. Own processing.

Further we have looked at the data available of European innovation index. The data were available for years 2012-2017. We have compared the mean value as well as the standard deviation. Again, we cannot observe any significant deviations over the time. Countries in the Figure 2. Are ranked based on the mean value, where Switzerland had the highest index, followed by Sweden and Denmark.

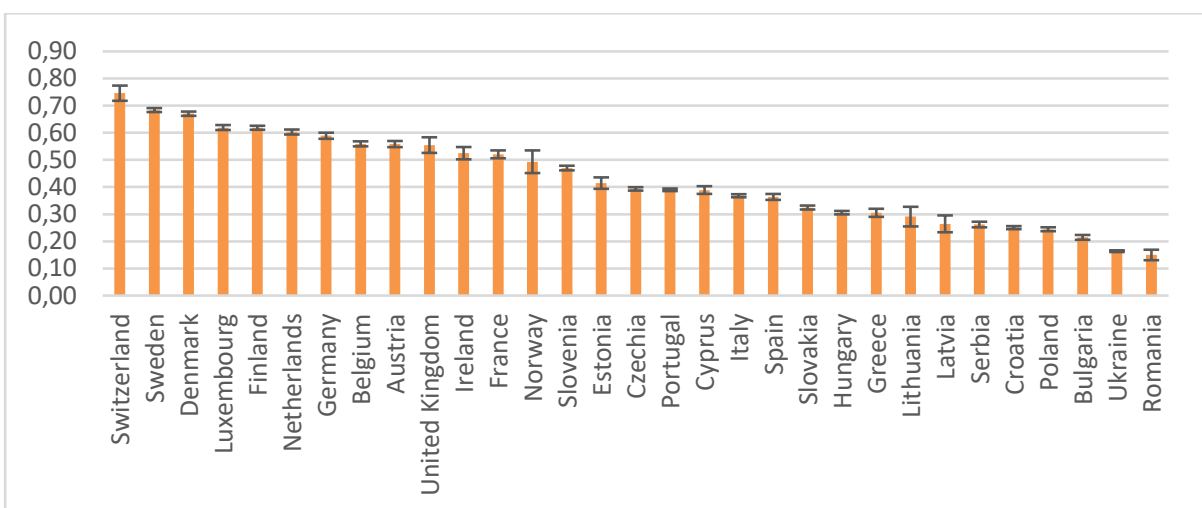

Figure 2: Mean value distribution and standard deviation for Innovation index. Own processing.

With performing the cluster analysis, we have first divided countries based on single variable - index in this case, to observe the distribution. Using K-means clustering, we can see that for HDI index, European countries in first cluster are Sweden, Norway, Finland, United Kingdom, Ireland, Denmark, Germany, Switzerland, Belgium and Netherlands. For Innovation index the countries in the first cluster were Switzerland, Sweden, Denmark, Luxemburg and Netherlands. 

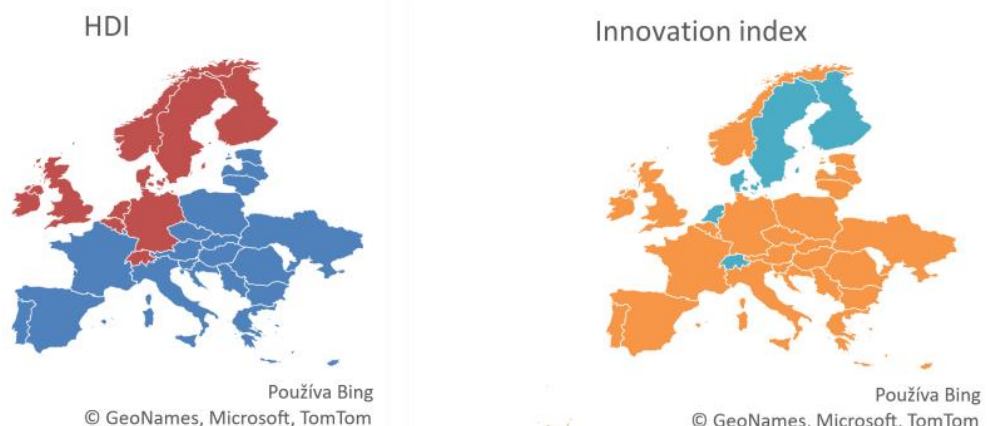

Figure 3: Cluster distribution for HDI index and Innovation index, respectively. Own processing.

When calculating cluster analysis used both indexes - HDI and innovation index we observe different clustering. The line between two clusters divides countries into northwestern and south-eastern. From the Baltic countries, Estonia belongs to countries from the northern Europe (as Sweden, Finland and Norway). Former Czechoslovakia is on the edge, were Czech Republic is in the western cluster, while Slovak Republic is in the eastern. From the southern countries, Spain and Portugal belong to the west, while Italy belongs to the east.

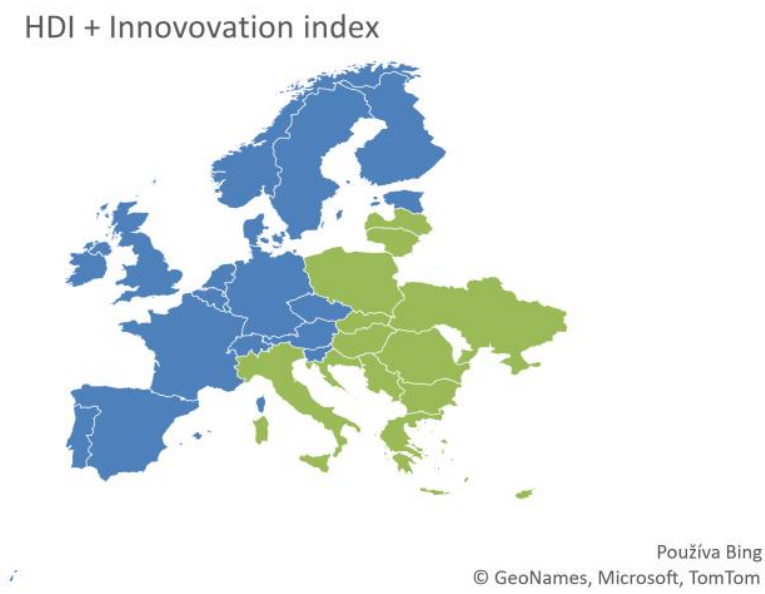

Figure 4: Cluster distribution for HDI and Innovation index combined. Own processing.

In the model we have worked with GDP per capita to control for the changes in cluster distribution. With GDP per capita applied in the model in 1000000 , there can by observed no change to the previous model without GDP per capita. The clusters remained the same. If we use GDP per capita in 100 000, with the increased weight of the variable, the clusters - line slightly change. Countries as Estonia, Czech Republic, Slovenia, Spain and Portugal move from the "western" cluster to the "eastern" cluster. 

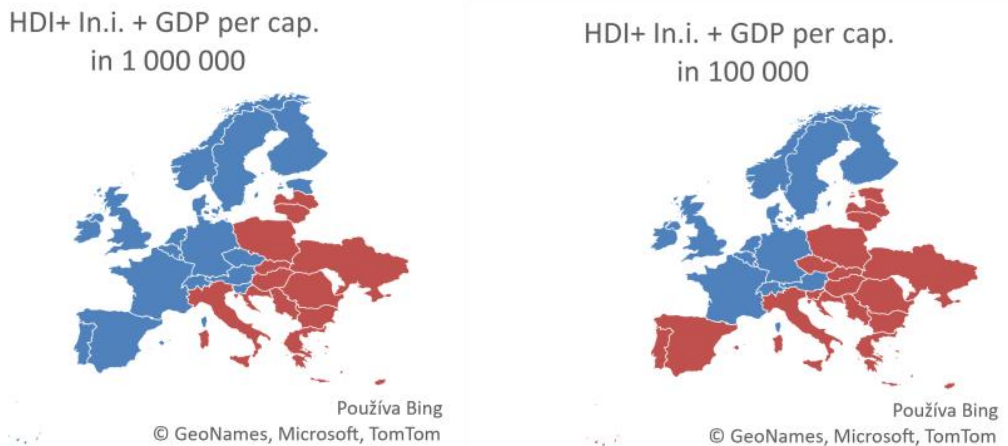

Figure 5: Cluster distribution with all indexes, GDP per capita in 1000000 and 100 000, respectively. Own processing.

Variables that we chose for the purpose of this analysis were indexes HDI and Innovation index, that are both created based upon other variables in the index. From the methodological perspective we have not found these indexes to be based upon the same data. The correlation analysis has shown, that there is a strong correlation between Human development index and Innovation index (while innovation index is much more focused on organizational performance, cooperation of companies and research and development). Further GDP per capita is similar to GNI per capita, that is used in HDI index, thus there can be explained the correlation of 0,788 . GDP per capita correlates with innovation index as well, with strong correlation of 0.838

\begin{tabular}{|c|c|c|c|}
\hline Correlation matrix & Innovation index & HDI & GDP per capita \\
\hline Innovation index & 1 & 0.908 & 0.838 \\
\hline HDI & 0.908 & 1 & 0.788 \\
\hline GDP per capita & 0.838 & 0.788 & 1 \\
\hline
\end{tabular}

Table 1: Correlation analysis do tested indexes.

\section{$5 \quad$ Discussion and conclusion}

Many researchers use comparative analyzes in their analytical research based on comparing differences between countries or regions. They seek to identify possible sources or causes of the identified outcomes or behaviors of individuals or societies in that country. Such a comparative analysis is a suitable research tool, especially if it is supplemented by time range research and with verification of trends or a stable position over a longer period of time.

This is important in social science research, given the impact of national differences and culture on the research studies. This article is also a consequence of our previous research, in which we have examined with different methods and at different times the differences in approaches to strategic management topics and innovations, as in the results expressed by innovation and competitiveness (Kohnová et al. 2020, Kohnová et 
al. 2019a, Kohnová et al. 2019b, Kohnová et al. 2019c, Kohnová et al. 2019d, Kohnová et al. 2017, Kohnová et al. 2017, Papula et al. 2018, Papula et al. 2013).

Other researchers also address these topics in relation to innovation (Stacho et al. 2020, Lorincová et al. 2020, Ližbetinová et al. 2016), human resource management (Poór et al. 2018, Blštáková et al. 2019), employee motivation and satisfaction (Hitka et al. 2014, Fagher 2008) and related managerial topics (Remišová et al. 2013, Šajgalíková et al. 2017.

These and many other studies pointed to the importance of national cultures, and to the significant differences of countries, in the behavior of their enterprises, individuals or groups, in statistical terms. As we mentioned, many authors in social science research work with the results of new research in the field of national culture. But in our research, we have identified the need to point out that studies and research focused on national cultures and cultural differences from an earlier period are still relevant and valid. With this research presented in this article, we have also proved the relevance and validity of the research of Johnn Hajnal and his Hajnal line.

And why is this research relevant and meaningful to current social science research? Today, at the beginning of the 4th Industrial Revolution, known as Industry 4.0, we are looking for answers to various questions in research, from which it would be possible to formulate functional recommendations for the national economy. Like every industrial revolution so far, the 4th Industrial Revolution creates unique opportunities. And not just for businesses, but for entire countries and regions. Which countries and regions make the right use of emerging opportunities can make a significant step forward. However, when formulating recommendations, we cannot go against the characteristics and natural characteristics of society expressed by the specifics of national culture. It is especially important for us in Slovakia to realize that, despite the common history with Austria within Austria-Hungary and more than 40 years of common history with the Czechs within Czechoslovakia, we note differences in approaches and attitudes of companies and managers in these countries.

Therefore, even with this research article we want to point out the historically named difference of national cultures, which is also reflected in significant results through which we evaluate the performance of countries. This performance was influenced by the behavior of individuals, groups, companies and society as a whole. Therefore, the measures and recommendations that need to be formulated to seize the opportunities of Industry 4.0 must be in line with national cultures and not universal and identical for all countries in Europe.

We also see inspiration for several anthropological researches, as well as researches on Gene-Culture and Co-Evolution (Marriot et al. 2016, Granqvist 2020, Frost 2017). The scope of perspectives that we should take into account is so much broader than the scope of research that is presented in most research articles. 


\section{Acknowledgments}

This research was supported and funded by APVV-17-0656 titled Transformation of Paradigm in Management of Organizations in the Context of Industry 4.0

\section{References}

1. Alkema, P.: A Sentiment Scale For Agile Team Environments in Large Organizations: A Grounded Theory. University of the Witwatersrand (2020).

2. Amar, H., Haag, M: Exploring the Critical Success Factors of Virtual-Agile IT Projects: A Grounded Theory Study. International Journal of Innovation, Management and Technology 8(6), 427-434 (2017).

3. Barker, J. R.: Tightening the Iron Cage: Concertive Control in Self-Managing Teams. Administrative Science Quarterly 38(3), 408-437 (1993).

4. Blštáková, J., Joniaková, Z., Skorková, Z. Némethová, I. - Bednár, R. 2019. Causes and Implications of the Applications of the Individualisation Principle in Human Resources Management. In AD ALTA : journal of interdisciplinary research. MAGNANIMITAS. vol. 9, no. 2, pp. 323-327, ISSN 2464-6733 .

5. ManagementSolutions, Homepage, https://www.managementsolutions.com/sites/default/files/publicaciones/eng/agile-organizations.pdf, last accessed 2020/06/15.

6. Capgemini consulting Homepage, https://www.capgemini.com/wp-content/uploads/2019/11/Report-\%E2\%80\%93-Agile-@-Scale-1.pdf, last accessed 2020/06/14.

7. Cockburn, A., Highsmith, J.: Agile software development: The people factor. Computer 34(11), 131-133 (2001).

8. Deloitte Development LLC Homepage, https://www2.deloitte.com/content/dam/Deloitte/ie/Documents/Technology/methods_in_systems_integration.pdf, last accessed 2020/06/15.

9. Doeze Jager-Van Vliet, S. B., Born, M., Molen, H. T.: Using a portfolio-based process to develop agility among employees. Human Resource Development Quarterly, 1-22 (2019).

10. Fargher, S., Kesting, S., Lange, T. Pacheco, G. (2008) Cultural heritage and job satisfaction in Eastern and Western Europe, International Journal of Manpower, Vol. 29 Issue: 7, pp.630650

11. Frost, P. 2017. The Hajnal Line and Gene-Culture Coevo-lution in Northwest Europe. Advances in Anthropology, 7, 154-174. https://doi.org/10.4236/aa.2017.73011

12. Goodman, P. S., Devadas, R., Hughson, T. L.: Groups and productivity: Analyzing the effectiveness of self-managing teams. Productivity in organizations, 295-325 (1988).

13. Granqvist, P. 2020. Attachment, culture, and gene-culture co-evolution: expanding the evolutionary toolbox of attachment theory, Attachment \& Human Development, ISSN: 1461-6734, https://doi.org/10.1080/14616734.2019.1709086

14. Guzzo, R. A., Dickson, M. W.: Teams in Organizations: Recent Research on Performance and Effectiveness. Annual Review of Psychology 47, 307-338 (1996).

15. Hitka, M., Balazova, Z. 2014. Comparison of Motivation Level of Service Sector Employees in The Regions of Slovakia and Austria. 2nd Global Conference on Business, Economics and Management and Tourism (BEMTUR) Prague, Procedia Economics and Finance, Volume:23, pp.348-355

16. Hoda, R., Murugesan, L. K.: Multi_level Agile Project Management Challenges: A SelfOrganizing Team Perspective. The Journal of Systems and Software 117, 45-257 (2016). 
17. Hoda, R., Noble, J., Marshall, S.: Organizing self-organizing teams. International Conference on Software Engineering. Cape Town, South Africa (2010).

18. Hoda, R., Noble, J., Marshall, S.: Self-organizing roles on agile software development teams. IEEE Transactions on Software Engineering, 39(3), 422-444 (2013).

19. Holbeche, L.: The Agile Organization. How to build an innovative, sustainable and resilient business. $1^{\text {st }}$ ed. Kogan Page Limited, London, UK (2015).

20. Chow, T., Cao, D.-B.: A survey of critical success factors in agile software projects. The Journal of Systems and Software 81, 961-971 (2007).

21. Kohnová L., Papula J., Papulová Z. (2020) Cooperation Models for Employee Education: Analysis on Slovak and Czech Companies. In: Cagáňová D., Horňáková N. (eds) Mobility Internet of Things 2018. Mobility IoT 2018. EAI/Springer Innovations in Communication and Computing. Springer, Cham

22. (a)Kohnová, L., Papula, J. (2019) Who Drives Innovation Activities? Evidence from Innovative European Countries. Proceedings of the 15th European Conference on Management, Leadership and Governance. Porto: Academic Conferences and Publishing International Limited.ISBN: 978-1-912764-47-1, pp. 236-255.

23. (b)Kohnová, L., Papula, J. (2019) Trust in Business Partnerships and its Effect on Mutual Benefits of Cooperation. Proceedings of the 10th European Conference on Intangibles and Intellectual Capital. Pescara: Academic Conferences and Publishing International Limited. ISBN: 978-1-912764-18-1,pp. 154-162.

24. (c)Kohnová, L., Papula, J., Salajová, N. (2019) Innovation Typology: Comparative Study on Central European Countries. Proceedingsof the 7th International Conference - Innovation Management, Entrepreneurship and Sustainability 2019. Prague: University of EcomonicsISBN 978-80-245-2316-3, pp. 334-348

25. (d)Kohnova L., Papula J., Salajova N. (2019) Internal factors supporting business and technological transformation in the context of Industry 4.0. Business: Theory and practice 20: 137-145, doi: 10.3846/btp.2019.13

26. Kohnová, L., Papula, J., Papulová, Z., Suchoba, M. 2017. Preparation for Smart Industry, Introduction and the Comparative Study. SMART CITY 360 The second EAI International Summit, Bratislava, Slovakia, DOI: 10.4108/eai.14-2-2017.152251

27. KPMG Homepage, https://assets.kpmg/content/dam/kpmg/in/pdf/2017/10/Qualityinagileteams.pdf, last accessed 2020/06/14.

28. Lizbetinova, L., Lorincova, S., Caha, Z,. 2016. The Application of the Organizational Culture Assessment Instrument (OCAI) to Logistics Enterprises. NASE MORE Volume: 63, Issue: 3 , pp: $170-176$

29. Lorincová, S., Stachová, K., Stacho, Z., Joniaková, Z., Blštáková, J., Lipoldová, M., Hitka, M. 2020 Defining the differences in corporate culture in wood-processing and forest enterprises BioResources 15(2), pp. 3320-3343

30. Marriott, C., Chebib, J. 2016. Modeling the Evolution of Gene-Culture Divergence. ArXiv, abs/1604.07108.

31. Moe, N. B., Dingsøyr, T., Dybå, T.: Understanding Self-Organizing Teams in Agile Software Development. Conference: Software Engineering, ASWEC. 19th Australian Conference on Software Engineering (2008).

32. Moe, N. B., Dybå, T., Cruzes, D., Engebretsen, E.: Coaching a Global Virtual Team. 10th International Conference on Global Software Engineering (2015).

33. Moreira, M.: Being Agile: Your Roadmap to Successful Adoption of Agile. $1^{\text {st }}$ ed. Apress (2013). 
34. Papula, J., Kohnova, L., Papulova, Z. Impact of national culture on innovation activities of companies: a case of Germany, Austria, Switzerland and the Czech Republic Economic Annals-XXI (2018), 169(1-2), 26-30

35. Papula, J., Volná, J., Hul'vej, J. (2013) "Knowledge networks as a source of knowledge initiatives and innovation activity in small and medium enterprises", Proceedings of International Conference KDIR 2013 and KMIS 2013 Algarve: Scitepress, ISBN 978-989-856575-4. pp. 389-396

36. Poór, J., Engle, A. D., Blštáková, J., Joniaková, Z. 2018. Internationalisation of human resource management: focus on Central and Eastern Europe. 1st ed. New York: Nova Science Publishers. European political, economic and security issues. ISBN 978-1-53612-632-7.

37. Remišová, A., Lašáková, A., Krzykala-Schaefer, R. 2013. Corporate social responsibility in European countries: The keystones of the concept and intercultural connotations, Journal for East European Management Studies. - vol. 18, no. 4 (2013), pp. 512-543, ISSN 0949-6181

38. Salin, N.: Supporting proactivity in agile project teams through self-organizing and shared leadership. LUT School of Business and Management (2017).

39. Sherehiy, B., Karwowski, W.: The relationship between work organization and workforce agility in small manufacturing enterprises. International Journal of Industrial Ergonomics 44, 466-473 (2014).

40. Smith, R.: Adopting 'Agile Leadership' in The Police Service. Scottish Institute for Policing Research, School of Social Sciences, University of Dundee, Dundee DD1 4HN (2008).

41. Spiegler, S. V., Heinecke, Ch., Wagner, S.: Leadership Gap in Agile Teams: How Teams and Scrum Masters Mature. LNBIP 355, 37-52 (2019).

42. Stacho, Z.; Stachova, K.; Caganova, D. Participation of all Employee Categories in Innovation Processes in Slovak Organisations. Mobile Networks and Applications 2020, 1-7, doi: 10.1007/s11036-020-01518-2

43. Stray, V., Moe, N. B., Hoda, R.: Autonomous agile teams: Challenges and future directions for research. 19th International Conference on Agile Software Development. In Proceedings of XP'18 Companion, Porto, Portugal (2018).

44. Šajgalíková, H., Copuš, L., Poláková, M. 2017. Where is the happiness-generated optimism streamed in? European perspective. Education excellence and innovation management through Vision 2020: From regional development sustainability and competitive economic growth. Norristown, PA, pp. 3235-3244, ISBN 978-0-9860419-7-6.

45. Šochová, Z., Kunce, E.: Agilní metody řízení projektů. $1^{\text {st }}$ ed. Computer Press, Brno (2014).

46. Whithworth, E., Biddle, R.: The Social Nature of Agile Teams. IEEE Explore, Washington, DC, USA (2007).

47. Livermore, D. 2011. The Cultural Intelligence Difference. New York: AMACOM.

48. Zaltman, G. 2003. How Customers Think. Boston, MA: Harvard Business School Publishing.

49. Senge, P. 2006. The Fifth Discipline - The Art \& Practice of the Learning Organisation. London: Random House Business Books. 